\title{
Total arterial revascularization in patients with acute myocardial infarction - feasibility and outcomes
}

\author{
Philippe Grieshaber ${ }^{1 *} \mathbb{D}$, Lukas Oster ${ }^{2}$, Tobias Schneider', Victoria Johnson³, Coskun Orhan', Peter Roth', \\ Bernd Niemann ${ }^{1}$ and Andreas Böning ${ }^{1}$
}

\begin{abstract}
Background: In acute situations such as acute myocardial infarction (AMI) with indication for coronary artery bypass grafting (CABG), total arterial revascularization (TAR) is often rejected in favour of saphenous vein (SV) grafting, which is assumed to allow for quicker vessel harvesting, a simpler anastomosis technique, and thus quicker revascularization and fewer bleeding complications. The aim of this study was to evaluate whether reluctance to apply TAR in AMl is still justified from a technical point of view in the current era and whether superiority of TAR results is also evident in emergency patients with AMl undergoing CABG.

Methods: In this retrospective analysis of 434 consecutive patients undergoing CABG for AMI with either TAR or with a combination of one internal mammary artery and SV grafts between 2008 and 2014, procedural data, short-term and mid-term outcome were compared. Propensity score matching of the groups was performed.

Results: After propensity score matching, 250 patients were included in the analysis (TAR group: $n=98$; SV group $n=152$ ). The procedural time (TAR group: 211 min vs. SV group: $200 \mathrm{~min}, p=0.46$ ) did not differ between the groups. Erythrocyte transfusion rates were higher in the SV group (76\% vs. 57\%; $p<0.001$ ). Rates of re-exploration for bleeding did not differ. Thirty-day mortality rates were comparable (TAR group: $3.4 \%$ vs. SV group: $4.5 \%, p=0.68$ ). Kaplan-Meier analysis until 7 years postoperatively revealed a tendency for improved survival after TAR (75\% vs. 62\%; log-rank $p=0.12$ ).
\end{abstract}

Conclusion: TAR neither impairs rapid revascularization nor reduces its safety in patients with AMI. It may result in improved long-term outcome and should be preferred in the clinical setting of AMI.

Keywords: Acute myocardial infarction, Coronary artery disease, Coronary artery bypass grafting surgery, Revascularization, Total arterial revascularization

\section{Background}

The use of arterial grafts for coronary artery bypass grafting surgery (CABG), particularly bilateral internal mammary arteries (BIMA), is recommended due to the superior patency of these grafts compared with saphenous vein grafts (SV grafts) [1]. In real-world practice, however, the utilization of total arterial revascularization (TAR) lags behind these recommendations [2-5]. Reasons for reluctance to conduct total arterial CABG even in stable patients include the increased technical demand, the

\footnotetext{
* Correspondence: Philippe.grieshaber@chiru.med.uni-giessen.de ${ }^{1}$ Department of Adult and Pediatric Cardiovascular Surgery, University Hospital Giessen, Rudolf-Buchheim-Str. 7, DE-35392 Giessen, Germany Full list of author information is available at the end of the article
}

increased operation time, and fear of bleeding complications and impaired wound healing [6-8]. In patients undergoing $\mathrm{CABG}$ for acute myocardial infarction (AMI), large-scale data on TAR rates is limited, and rates ranging from 2 to $58 \%$ have been described $[9,10]$. In the unstable situation of AMI, the above-mentioned arguments against total arterial CABG might play an even more important role for decision-making, as patients with AMI undergoing urgent or emergent surgery would be expected to benefit from short operation times and rapid revascularization afforded by use of venous grafting. Furthermore, AMI patients are frequently administered dual antiplatelet therapy (DAPT) preoperatively, resulting in increased risk of bleeding complications [11-13]. 
It is currently unclear whether these concerns about the use of TAR in patients with AMI are valid in the current era of surgical myocardial revascularization. Furthermore, the possible effect of total arterial CABG on long-term outcome in AMI patients has never been explicitly investigated.

\section{Methods}

\section{Study population}

We conducted a retrospective, single-centre study comparing patients undergoing total arterial CABG (total arterial revascularization group [TAR group]) or CABG with a combination of one internal mammary artery (IMA) and saphenous vein grafts (saphenous vein graft group [SV group]). Adult patients with a diagnosis of AMI (non-ST-segment elevation myocardial infarction [NSTEMI] or ST-segment-elevation myocardial infarction [STEMI]) within a period of 5 days or less before CABG without concomitant procedures (e.g. valve surgery) between $01 / 2008$ and $12 / 2014$ were included in the analysis. Patients with low cardiac output syndrome (LCOS) or cardiogenic shock at the time of surgery were excluded. The local ethics committee approved the study.

\section{Data collection, follow-up, definitions}

Patients were identified according to the inclusion criteria from institutional patient records, and their baseline characteristics and perioperative data from the patient records and from data transferred to the nationwide quality assurance system (BQS Institute for Quality and Patient Safety, Hamburg, Germany) were analysed. Long-term follow-up was conducted via telephone interviews with the patients or their family physicians.

AMI was defined according to the Third Universal Definition of AMI [14]. The time of AMI was defined as the time of symptom onset. 'Complete revascularization' was defined using the concept of anatomical complete numeric revascularization' (bypassing of all vessels $\geq 1 \mathrm{~mm}$ with hemodynamically relevant stenosis, as assessed by coronary angiography) [15]. We quantified the surgeon's experience according to the years in practice since board certification as cardiac surgeon.

\section{Endpoints}

We compared intraoperative parameters (duration of surgery, completeness of revascularization), perioperative need for invasive ventilation, perioperative transfusion requirements and bleeding complications, acute kidney injury as defined by KDIGO (Kidney disease: improving global outcomes) [16], sternal wound impairment requiring surgical therapy, postoperative duration of intensive care unit stay and hospitalization, as well as short- and mid-term survival between the groups.

\section{Management strategy}

Patients who underwent cardiac catheterization for AMI are referred to our unit immediately after completion of the angiographic diagnosis and the heart team-based decision for CABG. The timing of surgery is determined by the surgeon on duty. CABG with the goal of complete revascularization is routinely performed on-pump with cardioplegic arrest using cold-blood cardioplegia (Buckberg) [17]. Acetylsalicylic acid is started $6 \mathrm{~h}$ postoperatively and continued lifelong at $100 \mathrm{mg} /$ day. $\mathrm{P}^{2} \mathrm{Y}_{12}$ inhibitors are started on the first postoperative day and are continued for 12 months.

\section{Statistics}

An inferential statistical analysis was performed using SPSS Version 24 (IBM, Armonk, NY, USA), GraphPad Prism version 6 software (GraphPad Software, Inc., La Jolla, CA, USA), and R version 3.1.2. Patient characteristics and outcomes were compared using Fisher's exact test, Student's t-test, or Wilcoxon-Mann-Whitney test, as appropriate. Continuous variables are presented as mean \pm standard deviation (SD) unless stated otherwise.

In order to correct for potential confounding baseline parameters between the TAR group and the SV group, we carried out propensity score matching of the groups. Covariates included in the matching were age, gender, body-mass index, extent of coronary artery disease, preoperative left ventricular ejection fraction, diabetes mellitus (absence thereof, presence without insulin treatment, presence with insulin treatment), and EuroSCORE II. Nearest-neighbour matching in a 1:2 (TAR group vs. SV group) fashion was then performed. The maximum caliper between matched participants was set at 0.2. Long-term survival functions were determined using Kaplan-Meier estimation and compared using the log-rank test.

\section{Results \\ Baseline data}

A total of 434 patients were identified according to the inclusion criteria. Of these, 293 underwent CABG using a combination of one internal mammary artery and saphenous vein grafts, 3 underwent CABG with only vein grafts, and 138 underwent CABG using TAR. Baseline characteristics between the TAR group and the SV group differed significantly, with the TAR group having a lower proportion of female patients ( $17 \%$ vs. $29 \% ; p=0.011)$, a lower mean age (59 years vs. 71 years; $p<0.01$ ), a lower rate of chronic kidney disease and a lower rate of patients with severely reduced left-ventricular ejection fraction (Table 1). Consecutively, the operative risk estimation using EuroSCORE II was lower in the TAR group than in the SV group ( $3.4 \%$ vs. $7.2 \% ; p<0.01)$ (Table 1$)$. After propensity score matching, 250 patients (TAR group: $n=98$, SV 
Table 1 Baseline characteristics of the unmatched (left) and matched (right) groups

\begin{tabular}{|c|c|c|c|c|c|c|}
\hline \multirow[b]{2}{*}{ Parameter } & \multicolumn{3}{|c|}{ Unmatched study population } & \multicolumn{3}{|c|}{ Matched study population } \\
\hline & $\begin{array}{l}\text { SV group * } \\
n=296\end{array}$ & $\begin{array}{l}\text { TAR group * } \\
n=138\end{array}$ & $\overline{p \text {-value }}$ & $\begin{array}{l}\text { SV group * } \\
n=152\end{array}$ & $\begin{array}{l}\text { TAR group * } \\
n=98\end{array}$ & $\overline{p \text {-value }}$ \\
\hline Female gender & $85(29)$ & $24(17)$ & 0.011 & $33(22)$ & $21(21)$ & 0.96 \\
\hline Body mass index $\left(\mathrm{kg} / \mathrm{m}^{2}\right)$ & $28 \pm 4.7$ & $28 \pm 4.8$ & 0.31 & $28 \pm 5.0$ & $28 \pm 4.9$ & 0.99 \\
\hline Age, years & $71 \pm 9.2$ & $59 \pm 10$ & $<0.01$ & $66 \pm 9.6$ & $63 \pm 9.8$ & 0.08 \\
\hline NSTEMI & $202(68)$ & $95(69)$ & 0.90 & $105(69)$ & $70(71)$ & 0.69 \\
\hline STEMI & $94(32)$ & $43(31)$ & & $47(31)$ & $28(29)$ & \\
\hline \multicolumn{7}{|l|}{ Coronary artery disease } \\
\hline 1 vessel & $11(3.7)$ & $1(0.7)$ & $<0.01$ & $9(5.9)$ & $1(1.0)$ & 0.12 \\
\hline 2 vessel & $42(14)$ & $25(18)$ & & $21(14)$ & $18(18)$ & \\
\hline 3 vessel & $243(82)$ & $112(82)$ & & $122(80)$ & $79(81)$ & \\
\hline \multicolumn{7}{|l|}{ Diabetes mellitus } \\
\hline Without insulin & $81(27)$ & $26(19)$ & 0.054 & $42(27)$ & $20(20)$ & 0.19 \\
\hline With insulin & $50(17)$ & $15(11)$ & & $29(19)$ & $11(11)$ & \\
\hline \multicolumn{7}{|l|}{ Chronic kidney disease } \\
\hline Stage I (GFR > $89 \mathrm{ml} / \mathrm{min})$ & $\begin{array}{l}3(1.0) \\
120(41)\end{array}$ & $\begin{array}{l}0 \\
31(22.5)\end{array}$ & 0.034 & $\begin{array}{l}2(1.3) \\
57(38)\end{array}$ & $\begin{array}{l}0 \\
29(30)\end{array}$ & 0.13 \\
\hline Stage II (GFR 60-89 ml/min) & $75(25)$ & $10(7.2)$ & & $21(14)$ & $9(9.2)$ & \\
\hline Stage III (GFR 30-59 ml/min) & $\begin{array}{l}8(2.7) \\
11(3.7)\end{array}$ & $\begin{array}{l}1(0.7) \\
1(0.7)\end{array}$ & & $2(1.3)$ & $\begin{array}{l}1(1.0) \\
1(1.0)\end{array}$ & \\
\hline Stage IV (GFR 15-29 ml/min) & $11(3.7)$ & 0 & & $6(3.9)$ & 0 & \\
\hline Stage $V(G F R<15 \mathrm{ml} / \mathrm{min})$ & & & 0.046 & & & 0.092 \\
\hline \multicolumn{7}{|l|}{ Chronic dialysis } \\
\hline Arterial hypertension & $281(95)$ & $129(95)$ & 0.35 & $145(95)$ & $90(92)$ & 0.25 \\
\hline Hypercholesterinemia & $195(66)$ & $92(67)$ & 0.87 & $101(66)$ & $67(68)$ & 0.75 \\
\hline Cerebral arterial occlusive disease & $42(14)$ & $10(14)$ & 0.24 & $21(14)$ & $11(11)$ & 0.55 \\
\hline \multicolumn{7}{|l|}{ Peripheral arterial occlusive disease } \\
\hline Fontaine I & $6(2.0)$ & $1(0.7)$ & 0.078 & $5(3.2)$ & $1(1.0)$ & 0.46 \\
\hline Fontaine II & $31(10)$ & $11(8.0)$ & & $17(11)$ & $10(10)$ & \\
\hline Fontaine III & $5(1.7)$ & $1(0.7)$ & & $1(0.7)$ & $1(1.0)$ & \\
\hline Fontaine IV & $7(2.4)$ & $1(0.7)$ & & $2(1.3)$ & $1(1.0)$ & \\
\hline Chronic obstructive pulmonary disease & $32(11)$ & $11(8.0)$ & 0.36 & $16(11)$ & $8(8.2)$ & 0.54 \\
\hline $\mathrm{PCl}$ before $\mathrm{CABG}$ & $32(11)$ & $20(14)$ & 0.72 & $12(7.9)$ & $12(12)$ & 0.36 \\
\hline \multicolumn{7}{|l|}{ Preoperative LVEF } \\
\hline$<20 \%$ & $21(7.4)$ & $5(3.7)$ & 0.047 & $10(6.9)$ & $4(4.2)$ & 0.18 \\
\hline $20-30 \%$ & $27(9.5)$ & $4(3.0)$ & & $8(5.6)$ & $3(3.2)$ & \\
\hline $31-50 \%$ & $99(35)$ & $45(33)$ & & $57(40)$ & $29(31)$ & \\
\hline$>50 \%$ & $137(48)$ & $81(60)$ & & $69(48)$ & $59(62)$ & \\
\hline EuroSCORE ॥ & $7.2 \pm 8.1$ & $3.4 \pm 4.6$ & $<0.01$ & $5.3 \pm 6.1$ & $4.8 \pm 5.3$ & 0.14 \\
\hline
\end{tabular}

Abbreviations: CABG coronary artery bypass grafting, GFR glomerular filtration rate, LVEF left-ventricular ejection fraction, NSTEMI non-ST-segment elevation myocardial infarction, $P C I$ percutaneous coronary intervention, SV saphenous vein grafts, STEMI ST-segment-elevation myocardial infarction, TAR total arterial revascularization ${ }^{a}$ Continuous variables: mean \pm SD; categorical variables: $n(\%)$

group: $n=152$ ) remained in the analysis. The differences in baseline characteristics were eliminated (Table 1). All results described in the following refer to the matched groups. All patients received antiplatelet therapy before surgery, and $33 \%$ in the TAR group and $34 \%$ in the SV group $(p=0.71)$ were on DAPT at the time of surgery. Otherwise, tirofiban was used for bridging until $4 \mathrm{~h}$ before surgery (TAR group: $65 \%$ vs. SV group: $60 \% ; p=0.41$ ). 


\section{Intraoperative data}

The procedures were conducted at a median of $72 \mathrm{~h}$ after symptom onset by eight surgeons with a mean experience of $6.5 \pm 4.8$ years since board certification. Surgeon experience differed significantly between the groups (TAR group: $7.2 \pm 4.8$ years vs. SV group: $6.0 \pm 4.6$ years; $p=$ 0.042 ). In $86 \%$ of TAR procedures, BIMA grafting was applied, and $14 \%$ of patients received a combination of IMA and radial artery grafts. The total procedural times (TAR group: $211 \pm 54 \mathrm{~min}$ vs. SV group: $200 \pm 52 \mathrm{~min} ; p=0.46$ ) did not differ significantly between the groups. The time on cardiopulmonary bypass (CPB) was significantly shorter in the TAR group $(84 \pm 36 \mathrm{~min}$ vs. $96 \pm 43 \mathrm{~min}$; $p=0.048)$ and the duration of cardioplegic arrest was similar in the two groups (TAR group: $57 \pm 20 \mathrm{~min}$ vs. SV group: $58 \pm 21 \mathrm{~min} ; p=0.79$ ); however, the distribution of these phases was different, with a longer time to CPB in the TAR group $(89 \pm 20 \mathrm{~min}$. vs. $45 \pm 31 \mathrm{~min}$; $p=0.04)$ (Fig. 1). This discrepancy can be explained by procedural differences, as the harvesting of both IMA is performed sequentially, whereas the preparation of one IMA and vein grafts is usually carried out simultaneously. Interestingly, the time from the end of $\mathrm{CPB}$ to skin closure was significantly reduced in the TAR group $(36 \pm 10 \mathrm{~min}$ vs. $59 \pm$ $15 \mathrm{~min}, p=0.042$ ). The number of coronary anastomoses did not differ between the groups, and complete revascularization was achieved in 99\% (SV group) and 97\% (TAR group; $p=0.69$ ), respectively (Table 2 ).

The surgeon's experience had a significant inverse correlation with the total duration of the procedure $(2.9 \mathrm{~min}$ per year of experience), cardiopulmonary bypass time (2.3 min per year of experience), and cardioplegic arrest time (1.5 min per year of experience). There were no significant differences in this relationship between TAR and SV groups (Fig. 2).

\section{Perioperative outcomes}

Fifty-seven percent of TAR group patients received erythrocyte transfusion compared with $76 \%$ of SV group patients $(p=0.001)$. Platelet transfusion occurred in $36 \%$ (TAR group) and 37\% (SV group; $p=0.86$ ), respectively. Fresh frozen plasma was transfused in $22 \%$ of TAR group patients and $30 \%$ of SV group patients $(p=0.21)$. In those patients who received transfusions, the median amount of transfused erythrocyte units was higher in the SV group compared with the TAR group ( 2 vs. 1 unit; $p=0.041$ ). The amounts of platelet and fresh frozen plasma transfusions were comparable in both groups (Table 3). The rate of re-explorations due to bleeding was slightly lower in the TAR group than in the SV group (3.1\% vs. $5.9 \% ; p=$ 0.30 ) but this was not statistically significant. Interestingly, surgical revisions for sternal wound healing impairment were not significantly increased in the TAR group (4.0\%) compared with in the SV group $(2.6 \% ; p=0.52)$. Serum levels of troponin I and creatine kinase-isoform MB (CK$\mathrm{MB}$ ) increased postoperatively, which was followed by a decline until postoperative day 4 . The biomarker levels of the TAR group were slightly lower than those of the SV group, but this difference was not statistically significant (Fig. 3). Postoperative intermittent atrial fibrillation occurred less frequently in the TAR group than on the SV group $(10 \%$ vs. $19 \%, p=0.059)$. Acute kidney injury occurred similarly in both groups. Duration of invasive ventilation and rates of tracheostomies for long-term ventilation were comparable in both groups. Consecutively, the median durations of postoperative intensive care unit
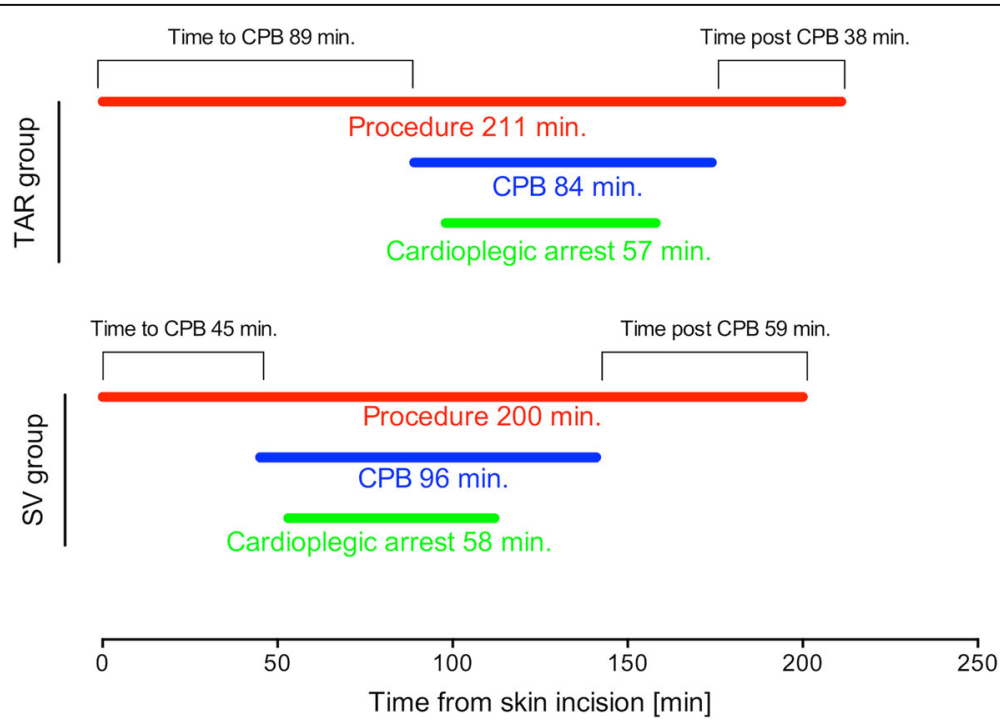

Fig. 1 Time course of surgical procedures with either total arterial revascularization or combination of one internal mammary artery and saphenous vein grafts. Abbreviations: CPB: cardiopulmonary bypass; SV: saphenous vein grafts; TAR: total arterial revascularization 
Table 2 Preoperative and intraoperative data

\begin{tabular}{|c|c|c|c|}
\hline Parameter & $\begin{array}{l}\text { SV group * } \\
n=152\end{array}$ & $\begin{array}{l}\text { TAR group * } \\
n=98\end{array}$ & $p$-value \\
\hline \multicolumn{4}{|l|}{ Antiplatelet therapy } \\
\hline ASA & $137(93)$ & $86(91)$ & 0.44 \\
\hline Ticagrelor & $9(6.1)$ & $10(11)$ & 0.20 \\
\hline Prasugrel & $3(2.0)$ & $3(3.2)$ & 0.57 \\
\hline Clopidogrel & $44(30)$ & $20(22)$ & 0.16 \\
\hline DAPT & $51(34)$ & $32(33)$ & 0.71 \\
\hline Tirofiban & $90(60)$ & $61(65)$ & 0.41 \\
\hline Vitamin $\mathrm{K}$ antagonists & $6(4.1)$ & $1(1.0)$ & 0.082 \\
\hline Time interval symptom onset to operation $(h)^{* *}$ & $72 \pm 5.1$ & $72 \pm 5.3$ & 0.85 \\
\hline \multicolumn{4}{|l|}{ Grafts } \\
\hline LIMA & $147(97)$ & $98(100)$ & $<0.001$ \\
\hline RIMA & $2(1.3)$ & $84(86)$ & \\
\hline Radial artery & 0 & $18(18)$ & \\
\hline Saphenous vein & $152(100)$ & 0 & \\
\hline \multicolumn{4}{|l|}{ Coronary anastomoses } \\
\hline Total & $3.8 \pm 1.1$ & $3.6 \pm 1.0$ & 0.11 \\
\hline Arterial grafts & $1.5 \pm 0.6$ & $3.6 \pm 1.0$ & $<0.001$ \\
\hline Venous grafts & $2.3 \pm 1.0$ & 0 & $<0.001$ \\
\hline \multicolumn{4}{|l|}{ Target vessels } \\
\hline LAD & $151(99)$ & $98(100)$ & 0.42 \\
\hline $\mathrm{RCX}$ & $132(89)$ & $87(89)$ & 0.59 \\
\hline RCA & $116(76)$ & $80(82)$ & 0.32 \\
\hline Complete revascularization [n; \%] & $149(99)$ & $95(97)$ & 0.69 \\
\hline
\end{tabular}

Abbreviations: CABG coronary artery bypass grafting, DAPT dual antiplatelet therapy, LAD left anterior descending artery, LVEF left ventricular ejection fraction, NSTEMI non-ST-segment elevation myocardial infarction, $P C I$ percutaneous coronary intervention, $R C A$ right coronary artery, $R C X$ Ramus circumflexus, SV saphenous vein grafts, STEMI ST-segment-elevation myocardial infarction, TAR total arterial revascularization

${ }^{a}$ Continuous variables: mean \pm SD; categorical variables: $n$ (\%)

${ }^{\mathrm{b}}$ Median \pm SD

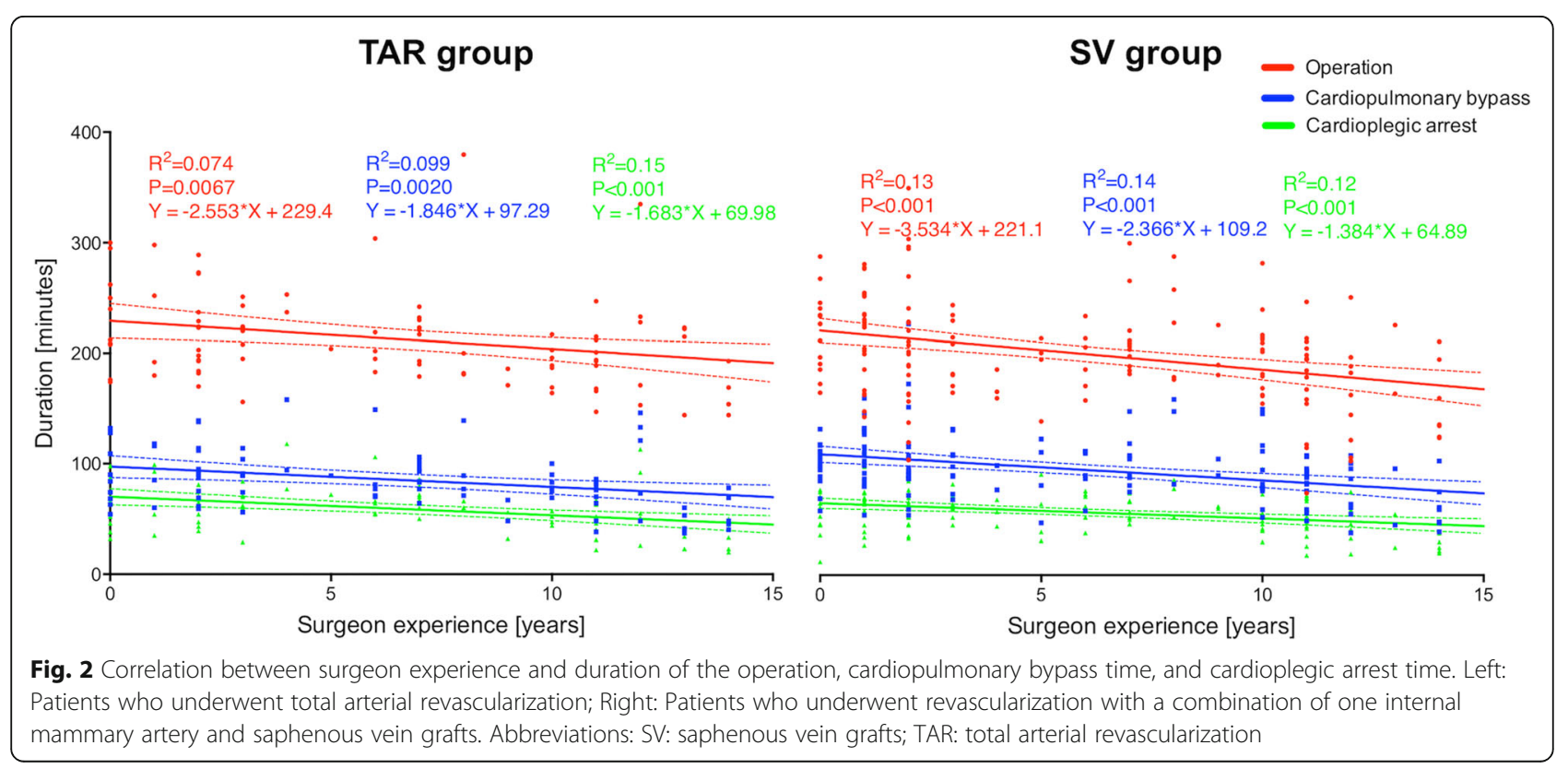


Table 3 Perioperative outcomes

\begin{tabular}{|c|c|c|c|}
\hline Parameter & $\begin{array}{l}\text { SV group * } \\
n=152\end{array}$ & $\begin{array}{l}\text { TAR group * } \\
n=98\end{array}$ & $p$-value \\
\hline \multicolumn{4}{|l|}{ Transfusions } \\
\hline \multicolumn{4}{|l|}{ Erythrocytes } \\
\hline Rate & $116(76)$ & $56(57)$ & $<0.001$ \\
\hline Amount (units)** & $2 \pm 2.6$ & $1 \pm 2.7$ & 0.041 \\
\hline \multicolumn{4}{|l|}{ Platelets } \\
\hline Rate & $56(37)$ & $35(36)$ & 0.86 \\
\hline Amount (units)** & $0 \pm 1.0$ & $0 \pm 0.90$ & 0.33 \\
\hline \multicolumn{4}{|l|}{ Fresh frozen plasma } \\
\hline Rate & $45(30)$ & $22(22)$ & 0.21 \\
\hline Amount (units)** & $0 \pm 2.0$ & $0 \pm 2.0$ & 0.46 \\
\hline Re-thoracotomy for bleeding & $9(5.9)$ & $3(3.1)$ & 0.30 \\
\hline Sternal wound healing impairment requiring surgical revision & $4(2.6)$ & $4(4.0)$ & 0.52 \\
\hline Superficial & $2(1.3)$ & $3(3.0)$ & \\
\hline Deep & $2(1.3)$ & $1(1.0)$ & \\
\hline Duration of invasive ventilation (hours) ${ }^{* *}$ & $14 \pm 58$ & $10 \pm 73$ & 0.61 \\
\hline Postoperative tracheostomy & $11(7.2)$ & $5(5.1)$ & 0.30 \\
\hline New onset atrial fibrillation & $29(19)$ & $10(10)$ & 0.059 \\
\hline Stroke (>Rankin1) & $3(2.0)$ & 0 & 0.1 \\
\hline \multicolumn{4}{|l|}{ Acute kidney injury } \\
\hline KDIGO I & $59(40)$ & $32(33)$ & 0.17 \\
\hline KDIGO ॥ & $11(7.5)$ & $4(4.1)$ & \\
\hline KDIGO III & $6(3.9)$ & $5(5.1)$ & \\
\hline Postoperative dialysis & $6(3.9)$ & $5(5.1)$ & 0.69 \\
\hline Postoperative length of ICU stay (hours)** & $73 \pm 81$ & $46 \pm 93$ & 0.28 \\
\hline Postoperative length of hospital stay (days) ** & $10 \pm 4.5$ & $10 \pm 3.4$ & 0.58 \\
\hline 30-day all-cause mortality & $6(4.5)$ & $3(3.4)$ & 0.68 \\
\hline
\end{tabular}

Abbreviations: ECLS extracorporeal life support, KDIGO Kidney disease: improving global outcomes, SV saphenous vein grafts, TAR total arterial revascularization ${ }^{a}$ Continuous variables: mean \pm SD; categorical variables: $n(\%)$

${ }^{\mathrm{b}}$ Median \pm SD

stay and postoperative hospitalization were similar in both groups. Other postoperative data were comparable between the groups (Table 3).

\section{Mortality and long-term follow up}

Mortality at 30 days postoperatively was $4.5 \%$ in the SV group and $3.4 \%$ in the TAR group $(p=0.68)$.. Further follow-up was complete for $92 \%$ of patients with a median follow-up time of $3.7 \pm 2.5$ years. Kaplan-Meier estimation of survival showed a tendency for improved survival in the TAR group ( $\log$-rank $p=0.12$ ) with survival curves beginning to diverge from 4 years postoperatively onwards. The overall survival probability at 7 years postoperatively was $75 \%$ in the TAR group and $62 \%$ in the SV group, respectively (Fig. 4). Symptom-driven repeat coronary angiography was reported by $17 \%$ of patients in the TAR group compared with $21 \%$ of patients in the SVG group $(p=0.45)$.
Redo-CABG was performed in 2 patients $(1.3 \%)$ in the SV group and 1 patient $(1.0 \%)$ in the TAR group $(p=0.64)$.

\section{Discussion}

The main finding of this analysis is that CABG using TAR is feasible in patients with AMI as it provides revascularization quality and patient safety like that of CABG using a combination of IMA and SV without increasing the time required for revascularization. Perioperative outcomes did not differ significantly between the groups. Bleeding complications and transfusion requirements were not higher after TAR than after revascularization using IMA/SV; in contrast, the proportion of patients who did not receive any red blood cell transfusion was higher in the TAR group. Postoperative atrial fibrillation was less frequent in the TAR group, possibly due to reduced red blood cell transfusion as demonstrated by previous studies $[18,19]$. 


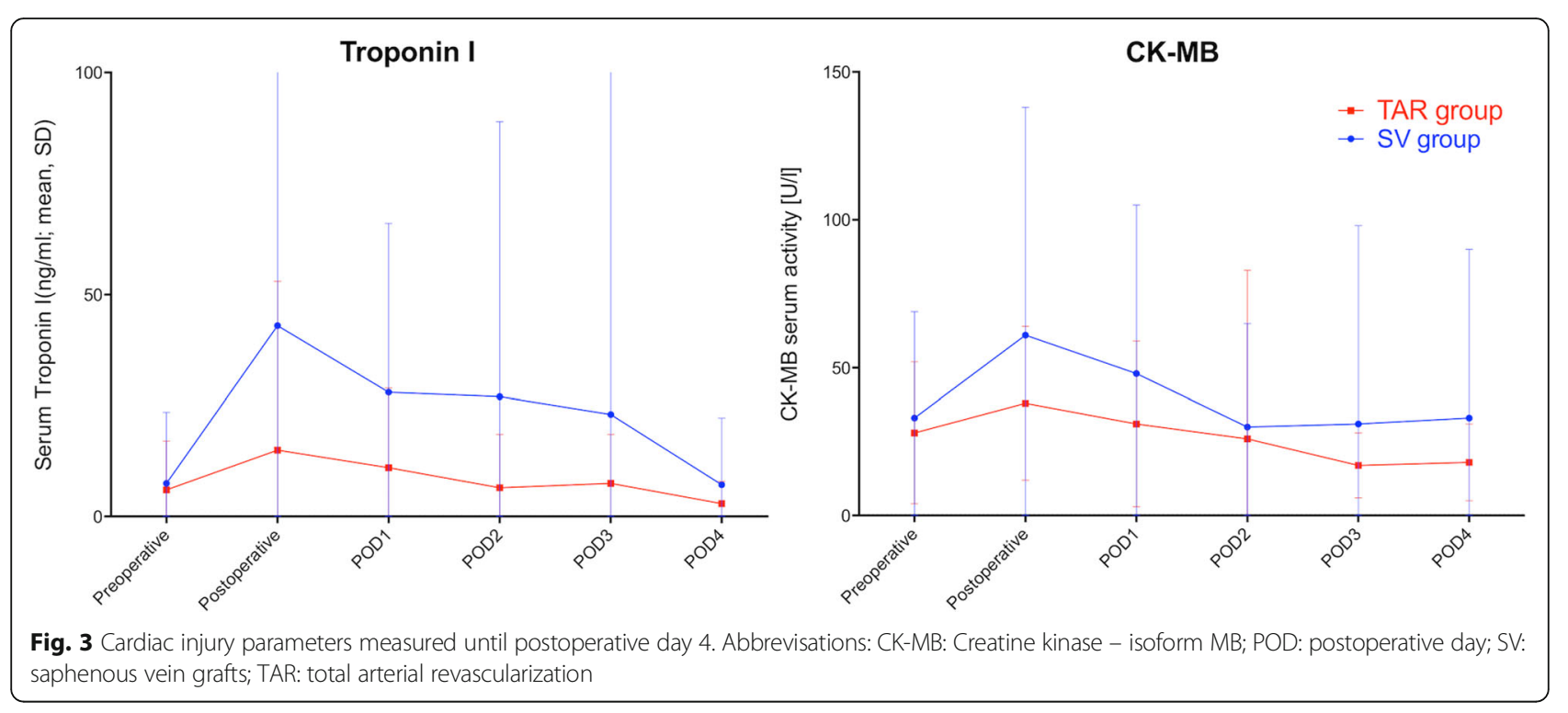

Nevertheless, if transfusions were necessary, the amount of transfused erythrocyte units was rather high. This might be explained by the high rate of patients with DAPT at the time of surgery [11].

The mean time of surgeon experience was slightly higher in the TAR group, probably reflecting that more experienced surgeons tend to perform this more challenging technique in urgent or emergent clinical settings. Moreover, the increased surgeon experience in the TAR group might result in better surgical results, although recent data did not confirm this assumption for CABG procedures

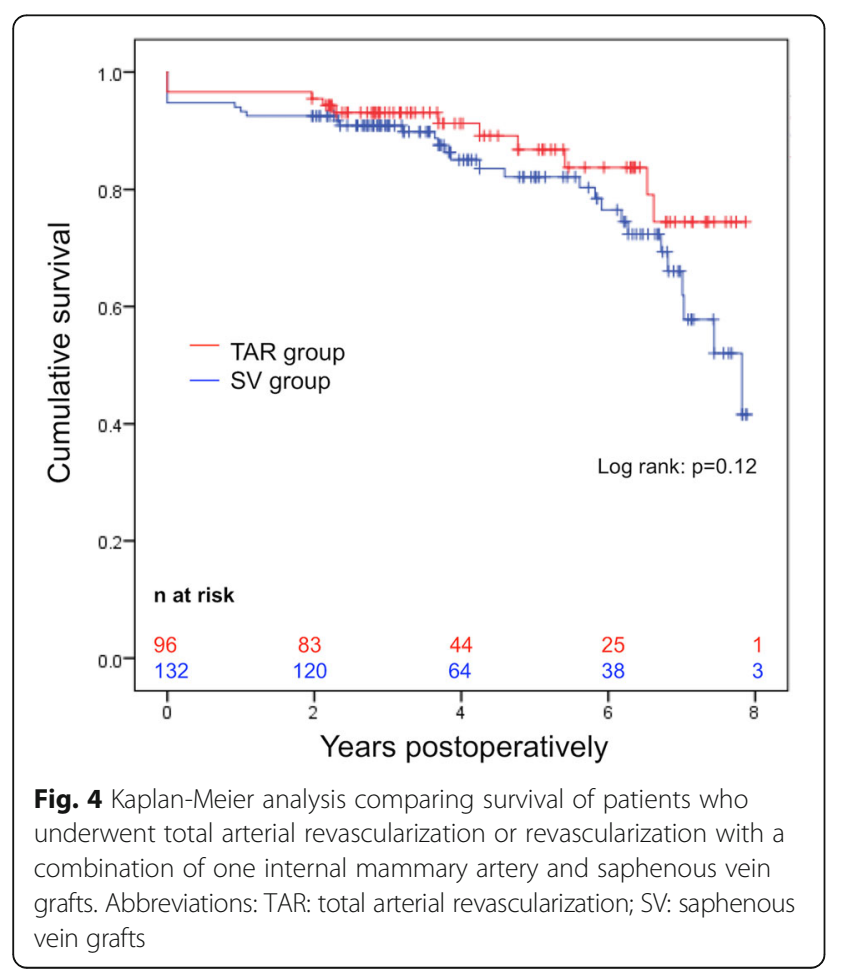

[20-22]. Surprisingly, analysis of procedural duration revealed that the total duration of the surgical procedures involving total arterial CABG and CABG using vein grafts were similar. Our data show that the surgeon's experience has a significant influence on the duration of the procedure but that the amount is of questionable relevance. The longer phase of graft preparation in the TAR group was balanced by a shorter post-CPB phase in the TAR group. The reduction in reperfusion time and post-CPB time might be partly explained by the greater experience of the surgeons involved, leading to more efficient management at the end of the operation; however, the shorter time could additionally be explained by more rapid bypass graft function of arterial grafts compared with vein grafts, possibly resulting in quicker hemodynamic stabilization. Data on flow properties of arterial bypass grafts compared those of with vein grafts in the immediate intraoperative phase are limited: Spence et al. showed in a canine model that mammary artery graft flow is not impaired by competitive flow from the native vessel [23]. As competitive flow from either the native vessel or collaterals is frequently observed in the early and late postoperative phase, resilience of the grafts may influence their immediate and long-term function [24]. Concerning the immediate function, Weber et al. described improved intraoperative pulsatility indices and a tendency for reduced perioperative myocardial infarctions when using IMA grafts compared with vein grafts [25]. We cannot substantiate our assumption of improved immediate bypass graft function, as flow measurements were not routinely carried out at our institution. Furthermore, although the postoperative increase in serum levels of cardiac biomarkers was somewhat less in the TAR group than in the SV group (possibly reflecting reduced cardiac injury resulting from improved bypass function), this difference was not statistically significant. 
We were also surprised to observe that the most technically challenging phase of the procedure, the completion of the coronary anastomoses during cardioplegic arrest, required the same amount of time in the two groups, which is not in keeping with the reluctance to perform TAR due to more difficult and prolonged completion of coronary anastomoses. In fact, the present data should encourage surgeons to commit themselves early to TAR concepts, as these are feasible without loss of time in experienced hands.

Data from the postoperative follow-up period of up to 7 years did not show significant differences in survival between the groups; however, there was a tendency for improved survival in the TAR group from 4 years onwards. The rate of reported symptom-driven repeat coronary catheterizations were non-significantly lower in the TAR group. Unfortunately, there is no information available about the results of these coronary catheterizations and interventions performed. Redo-CABG occurred similarly in both groups. Previous studies have demonstrated that differences in graft patency between SV and IMA grafts become evident only after $4-8$ years $[26,27,28]$. A survival benefit after TAR in the mid- or long-term has been shown in pooled analyses [29,30]. Our observation is in accordance with the recently published work by Taggart et al. showing no significant survival benefit after bilateral IMA versus single IMA grafting after 5 years [31]. A longer-term follow-up of the patients will be required to confirm these observations.

Several limitations of this study should be mentioned. First, patients with LCOS prior to surgery were excluded from this analysis, as CABG in these patients frequently does not follow the standardized sequence of operative steps. These patients are often placed on CPB prior to graft harvesting, and BIMA preparation is all but ruled out in these emergency situations, and hence we did not consider these exceptional, very individual situations to be suitable for a generalizable analysis. Therefore, the results of this study cannot be applied to patients who present with LCOS before CABG. Second, CPB with cardioplegic arrest was used in all procedures. Alternative approaches include off-pump CABG or on-pump CABG with beating heart [32-34], which might reduce injury and inflammation associated with $\mathrm{CPB}$ and cardioplegic arrest. $\mathrm{CPB}$ with cardioplegic arrest, however, provides hemodynamic stability during the procedure with optimized exposure for accurate anastomosing. To date there are no data available showing superiority of one strategy over the other.

Although the logistical and technical aspects (procedural times, completeness of revascularization) of our study are not likely to be biased by the study design, outcome data of this retrospective, propensity-matched analysis should be considered with caution. Unknown confounders might reduce comparability of the groups and bias outcome data.

\section{Conclusion}

TAR should be considered the standard of care in hemodynamically stable patients with AMI undergoing CABG, as it is equally safe and rapid compared with the use of combinations of IMA and vein grafts. Reluctance to apply TAR in these patients due to fear of protracted revascularization and bleeding complications is no longer justified. Long-term outcome may be improved after TAR, but these observations remain to be confirmed in a longer-term study.

\section{Abbreviations \\ AMI: Acute myocardial infarction; BIMA: Bilateral internal mammary artery; CABG: Coronary artery bypass grafting surgery; CK-MB: Creatine kinase, isoform MB; CPB: Cardiopulmonary bypass; LCOS: Low cardiac output syndrome; NSTEMI: Non-ST-segment elevation myocardial infarction; OR: Odds ratio; SD: Standard deviation; STEMI: ST-segment-elevation myocardial infarction; SV: Saphenous vein grafts; TAR: Total arterial revascularization}

\section{Acknowledgements}

T The authors thank Irina Oswald for excellent assistance during patient follow-up and Dr. Elizabeth Martinson for language editing of the manuscript.

\section{Funding}

This is an investigator-initiated project without external funding. The authors of this manuscript received external funding for other research projects from the following sources:

PG: The German Heart Foundation, the University Hospital Giessen and Marburg Research Fund, the Von-Behring-Röntgen-Foundation.

LO: none

TS: none

$\mathrm{VJ}$ : none

CO: none

PR: none

BN: The German Heart Foundation, the University Hospital Giessen and Marburg Research Fund, the Von-Behring-Röntgen-Foundation.

AB: The German Heart Foundation, the University Hospital Giessen and Marburg Research Fund, the Von-Behring-Röntgen-Foundation.

\section{Availability of data and materials}

All data generated or analysed during this study are included in this published article.

\section{Authors' contributions}

PG initiated and led the study, coordinated data collection and analysis as well as drafting of the manuscript. LO and TS carried out data collection and data anlysis and contributed in drafting the manuscript. PG, LO, TS, VJ, CO, $P R, B N$ and $A B$ drafted parts of the manuscript and all authors revised the manuscript critically and approved the manuscript finally.

\section{Ethics approval and consent to participate}

The ethical committee of the Faculty of Medicine at Justus Liebig University Giessen, Germany approved the study. The trial was designed and conducted in accordance to the Declaration of Helsinki. All patients gave general consent to collection and analysis of their data for scientific purposes prior to operation.

Consent for publication

Not applicable 


\section{Competing interests}

The authors of this manuscript have research support from The German Heart Foundation, the University Hospital Giessen and Marburg Research Fund, the Von-Behring-Röntgen-Foundation ( $P G, B N$ and $A B)$. The authors declare that there are no conflicting financial or non-financial interests. Al authors confirm that they had full control of the design and the methods of the study, the data analysis and the production of the written report.

\section{Publisher's Note}

Springer Nature remains neutral with regard to jurisdictional claims in published maps and institutional affiliations.

\section{Author details \\ 'Department of Adult and Pediatric Cardiovascular Surgery, University Hospital Giessen, Rudolf-Buchheim-Str. 7, DE-35392 Giessen, Germany. ${ }^{2}$ Department of Anaesthesiology, Sana Hospital Berlin-Lichtenberg, Berlin, Germany. ${ }^{3}$ Department of Cardiology and Angiology, University Hospital Giessen, Giessen, Germany.}

\section{Received: 14 September 2017 Accepted: 20 December 2017} Published online: 05 January 2018

\section{References}

1. Kolh P, Windecker S, Alfonso F, Collet J-P, Cremer J, Falk V, Filippatos G, Hamm C, Head SJ, Jüni P, Kappetein AP, Kastrati A, Knuuti J, Landmesser U, Laufer G, Neumann F-J, Richter DJ, Schauerte P, Sousa Uva M, Stefanini GG, Taggart DP, Torracca L, Valgimigli M, Wijns W, Witkowski A, ESC Committee for Practice Guidelines, Zamorano JL, Achenbach S, Baumgartner H, Bax JJ, Bueno H, Dean V, Deaton C, Erol Ç, Fagard R, Ferrari R, Hasdai D, Hoes AW, Kirchhof $\mathrm{P}$, Knuuti J, Kolh P, Lancellotti P, Linhart A, Nihoyannopoulos P, Piepoli MF, Ponikowski P, Sirnes PA, Tamargo JL, Tendera M, Torbicki A, Wijns W, Windecker S, Committee EACTSCG, Sousa Uva M, Achenbach S, Pepper J, Anyanwu A, Badimon L, Bauersachs J, Baumbach A, Beygui F, Bonaros N, De Carlo M, Deaton C, Dobrev D, Dunning J, Eeckhout E, Gielen S, Hasdai D, Kirchhof P, Luckraz H, Mahrholdt H, Montalescot G, Paparella D, Rastan AJ, Sanmartin M, Sergeant P, Silber S, Tamargo J, ten Berg J, Thiele H, van Geuns R-J, Wagner H-O, Wassmann S, Wendler O, Zamorano JL. 2014 ESC/EACTS guidelines on myocardial revascularization: the task force on myocardial revascularization of the European Society of Cardiology (ESC) and the European Association for Cardio-Thoracic Surgery (EACTS). Developed with the special contribution of the European Association of Percutaneous Cardiovascular Interventions (EAPCI). Eur J Cardio-Thorac Surg Off J Eur Assoc Cardio-Thorac Surg. 2014;46:517-92. https://doi.org/10.1093/ ejcts/ezu366.

2. Mohr FW, Rastan AJ, Serruys PW, Kappetein AP, Holmes DR, Pomar JL, Westaby S, Leadley K, Dawkins KD, Mack MJ. Complex coronary anatomy in coronary artery bypass graft surgery: impact of complex coronary anatomy in modern bypass surgery? Lessons learned from the SYNTAX trial after two years. J Thorac Cardiovasc Surg. 2011;141:130-40. https://doi.org/10.1016/j. jtcvs.2010.07.094.

3. ElBardissi AW, Aranki SF, Sheng S, O'Brien SM, Greenberg CC, Gammie JS. Trends in isolated coronary artery bypass grafting: an analysis of the Society of Thoracic Surgeons adult cardiac surgery database. J Thorac Cardiovasc Surg. 2012;143:273-81. https://doi.org/10.1016/j.jtcvs.2011.10.029.

4. Itagaki S, Cavallaro P, Adams DH, Chikwe J. Bilateral internal mammary artery grafts, mortality and morbidity: an analysis of 1526360 coronary bypass operations. Heart. 2013;99:849-53. https://doi.org/10.1136/heartjnl2013-303672.

5. Tabata M, Grab JD, Khalpey Z, Edwards FH, O'Brien SM, Cohn LH, Bolman RM. Prevalence and variability of internal mammary artery graft use in contemporary multivessel coronary artery bypass graft surgery. Circulation. 2009;120:935-40. https://doi.org/10.1161/CIRCULATIONAHA.108.832444.

6. Deutsch O, Gansera L, Wunderlich M, Eichinger W, Gansera B. Does bilateral ITA grafting increase Perioperative complications? Outcome of 6,476 patients with bilateral versus 5,020 patients with single ITA bypass. Thorac Cardiovasc Surg. 2015;64:188-94. https://doi.org/10.1055/s-0035-1558992.

7. Benedetto U, Altman DG, Gerry S, Gray A, Lees B, Pawlaczyk R, Flather M, Taggart DP. Pedicled and skeletonized single and bilateral internal thoracic artery grafts and the incidence of sternal wound complications: insights from the arterial revascularization trial. J Thorac Cardiovasc Surg. 2016;152: 270-6. https://doi.org/10.1016/j.jtcvs.2016.03.056.
8. Tavolacci M-P, Merle V, Josset V, Bouchart F, Litzler P-Y, Tabley A, Bessou J-P, Czernichow $P$. Mediastinitis after coronary artery bypass graft surgery: influence of the mammary grafting for diabetic patients. J Hosp Infect. 2003; 55:21-5. https://doi.org/10.1016/S0195-6701(03)00116-6.

9. Nichols EL, McCullough JN, Ross CS, Kramer RS, Westbrook BM, Klemperer JD, Leavitt BJ, Brown JR, Olmstead E, Hernandez F, Sardella GL, Frumiento C, Malenka D, DiScipio A. Optimal timing from myocardial infarction to coronary artery bypass grafting on hospital mortality. Ann Thorac Surg. 2017;103:162-71. https://doi.org/10.1016/j.athoracsur.2016.05.116.

10. Locker C, Mohr R, Paz Y, Kramer A, Lev-Ran O, Pevni D, Shapira I. Myocardial revascularization for acute myocardial infarction: benefits and drawbacks of avoiding cardiopulmonary bypass. Ann Thorac Surg. 2003;76:771-6. https:// doi.org/10.1016/S0003-4975(03)00732-X.

11. Nagashima Z, Tsukahara K, Uchida K, Hibi K, Karube N, Ebina T, Imoto K, Kimura K, Umemura S. Impact of preoperative dual antiplatelet therapy on bleeding complications in patients with acute coronary syndromes who undergo urgent coronary artery bypass grafting. J Cardiol. 2017;69:156-61. https://doi.org/10.1016/j.jjcc.2016.02.013

12. Mahla E, Prueller F, Farzi S, Pregartner G, Raggam RB, Beran E, Toller W, Berghold A, Tantry US, Gurbel PA. Does platelet reactivity predict bleeding in patients needing urgent coronary artery bypass grafting during dual Antiplatelet therapy? Ann Thorac Surg. 2016;102:2010-7. https://doi.org/10. 1016/j.athoracsur.2016.05.003.

13. Siller-Matula JM, Petre A, Delle-Karth G, Huber K, Ay C, Lordkipanidzé M, Caterina RD, Kolh P, Mahla E, Gersh BJ. Impact of preoperative use of P2Y12 receptor inhibitors on clinical outcomes in cardiac and non-cardiac surgery: a systematic review and meta-analysis. Eur Heart J Acute Cardiovasc Care. 2015:2048872615585516. https://doi.org/10.1177/2048872615585516.

14. Thygesen K, Alpert JS, Jaffe AS, Simoons ML, Chaitman BR, White HD. Third universal definition of myocardial infarction. Circulation. 2012;126:2020-35. https://doi.org/10.1161/CIR.0b013e31826e1058.

15. Ong ATL, Serruys PW. Complete Revascularization. Circulation. 2006;114:24955. https://doi.org/10.1161/CIRCULATIONAHA.106.614420.

16. Khwaja A. KDIGO clinical practice guidelines for acute kidney injury. Nephron Clin Pract. 2012;120:C179-84. https://doi.org/10.1159/000339789.

17. Böning A, Rohrbach S, Kohlhepp L, Heep M, Hagmüller S, Niemann B, Mühlfeld C. Differences in ischemic damage between young and old hearts-effects of blood cardioplegia. Exp Gerontol. 2015;67:3-8. https://doi. org/10.1016/j.exger.2015.04.012.

18. Alameddine AK, Visintainer P, Alimov VK, Rousou JA. Blood transfusion and the risk of atrial fibrillation after cardiac surgery. J Card Surg. 2014;29:593-9. https://doi.org/10.1111/jocs.12383.

19. Koch CG, Li L, Van Wagoner DR, Duncan Al, Gillinov AM, Blackstone EH. Red cell transfusion is associated with an increased risk for postoperative Atrial fibrillation. Ann Thorac Surg. 2006;82:1747-56. https://doi.org/10.1016/j. athoracsur.2006.05.045

20. Yount KW, Yarboro LT, Narahari AK, Ghanta RK, Tribble CG, Kron IL, Kern JA Ailawadi $\mathrm{G}$. Outcomes of trainees performing coronary artery bypass grafting: does resident experience matter? Ann Thorac Surg. 2017;103:975-81. https:// doi.org/10.1016/j.athoracsur.2016.10.016.

21. Ch'ng SL, Cochrane AD, Wolfe R, Reid C, Smith Cl, Smith JA. Procedure-specific cardiac surgeon volume associated with patient outcome following valve surgery, but not isolated CABG surgery. Heart Lung Circ. 2015;24:583-9. https:// doi.org/10.1016/j.hlc.2014.11.014.

22. Burt BM, ElBardissi AW, Huckman RS, Cohn LH, Cevasco MW, Rawn JD, Aranki SF, Byrne JG. Influence of experience and the surgical learning curve on long-term patient outcomes in cardiac surgery. J Thorac Cardiovasc Surg. 2015;150:1061-1068.e3. https://doi.org/10.1016/j.jtcvs.2015.07.068.

23. Spence PA, Lust RM, Zeri RS, Jolly SR, Mehta PM, Otaki M, Sun YS, Chitwood WR. Competitive flow from a fully patent coronary artery does not limit acute mammary graft flow. Ann Thorac Surg. 1992;54:21-5.

24. Glineur D, Hanet C. Competitive flow in coronary bypass surgery: is it a problem? Curr Opin Cardiol. 2012;27:620-8. https://doi.org/10.1097/HCO Ob013e3283583000.

25. Weber A, Tavakoli R, Genoni M. Superior flow pattern of internal thoracic artery over Saphenous vein grafts during OPCAB procedures. J Card Surg. 2009;24:2-5. https://doi.org/10.1111/j.1540-8191.2008.00730.x.

26. Fitzgibbon GM, Kafka HP, Leach AJ, Keon WJ, Hooper GD, Burton JR. Coronary bypass graft fate and patient outcome: angiographic follow-up of 5,065 grafts related to survival and reoperation in 1,388 patients during 25 years. J Am Coll Cardiol. 1996;28:616-26. https://doi.org/10.1016/0735-1097(96)00206-9. 
27. Goldman S, Zadina K, Moritz T, Ovitt T, Sethi G, Copeland JG, Thottapurathu $\mathrm{L}$, Krasnicka B, Ellis N, Anderson RJ, Henderson W. Long-term patency of saphenous vein and left internal mammary artery grafts after coronary artery bypass surgery: results from a Department of Veterans Affairs Cooperative Study. J Am Coll Cardiol. 2004;44:2149-56. https://doi.org/10. 1016/j.jacc.2004.08.064.

28. Gansera B, Schmidtler F, Angelis I, Kiask T, Kemkes BM, Botzenhardt F. Patency of internal thoracic artery compared to vein grafts - postoperative angiographic findings in 1189 symptomatic patients in 12 years. Thorac Cardiovasc Surg. 2007;55:412-7. https://doi.org/10.1055/s-2007-965372.

29. Weiss AJ, Zhao S, Tian DH, Taggart DP, Yan TD. A meta-analysis comparing bilateral internal mammary artery with left internal mammary artery for coronary artery bypass grafting. Ann Cardiothorac Surg. 2013;2:390-400. https://doi.org/10.3978/2399.

30. Taggart DP, D'Amico R, Altman DG. Effect of arterial revascularisation on survival: a systematic review of studies comparing bilateral and single internal mammary arteries. Lancet. 2001;358:870-5. https://doi.org/10.1016/ S0140-6736(01)06069-X.

31. Taggart DP, Altman DG, Gray AM, Lees B, Gerry S, Benedetto U, Flather M Randomized trial of bilateral versus single internal-thoracic-artery grafts. N Engl J Med. 2016;375:2540-9. https://doi.org/10.1056/NEJMoa1610021.

32. Miyahara K, Matsuura A, Takemura H, Saito S, Sawaki S, Yoshioka T, Ito H. On-pump beating-heart coronary artery bypass grafting after acute myocardial infarction has lower mortality and morbidity. J Thorac Cardiovasc Surg. 2008;135:521-6. https://doi.org/10.1016/j.jtcvs.2007.10.006

33. Gp V, Cs D, No T, Vh T, As E. Acute myocardial infarction: OPCAB is an alternative approach for treatment. Heart Surg Forum. 2001;4:147-50.

34. Nishi H, Sakaguchi T, Miyagawa S, Yoshikawa Y, Fukushima S, Yoshioka D, Saito T, Toda K, Sawa Y. Optimal coronary artery bypass grafting strategy for acute coronary syndrome. Gen Thorac Cardiovasc Surg. 2014;62:357-63. https://doi.org/10.1007/s1 1748-013-0358-6.

\section{Submit your next manuscript to BioMed Central and we will help you at every step:}

- We accept pre-submission inquiries

- Our selector tool helps you to find the most relevant journal

- We provide round the clock customer support

- Convenient online submission

- Thorough peer review

- Inclusion in PubMed and all major indexing services

- Maximum visibility for your research

Submit your manuscript at www.biomedcentral.com/submit 